\title{
EDDS and EDTA-enhanced zinc accumulation by solanum nigrum inoculated with arbuscular mycorrhizal fungi grown in contaminated soil
}

\author{
Ana P.G.C. Marques ${ }^{\text {a }}$, Rui S. Oliveira ${ }^{a}$, Kalina A. Samardjieva ${ }^{b}$, José Pissarra ${ }^{c}$, \\ António O.S.S. Rangel ${ }^{\text {a }}$, Paula M.L. Castro ${ }^{\mathrm{a}, *}$ \\ ${ }^{a}$ Escola Superior de Biotecnologia, Universidade Católica Portuguesa, Rua Dr. António Bernardino de Almeida, 4200-072 Porto, Portugal \\ ${ }^{\mathrm{b}}$ Instituto de Biologia Molecular e Celular, Universidade do Porto, Rua do Campo Alegre 823, 4150-180 Porto, Portugal \\ ${ }^{\mathrm{c}}$ Faculdade de Ciências da Universidade do Porto, Departamento de Botânica, Rua do Campo Alegre, 1191, 4150-181 Porto, Portugal
}

Keywords: Arbuscular mycorrhizal fungi; EDDS; EDTA; Phytoextraction; Solanum nigrum; Zn

\begin{abstract}
The effect of two different chelating agents [EDTA and EDDS ( $S, S$-ethylenediaminedissucinic acid)] on Zn tissue accumulation in Solanum nigrum L. grown in a naturally contaminated soil was assessed. Under those conditions, the response of the plant to the inoculation with two different isolates of arbuscular mycorrhizal fungi (AMF) - Glomus claroideum and Glomus intraradices - was also studied. Plants grown in the local contaminated soil ( $\mathrm{Zn}$ levels of $433 \mathrm{mg} \mathrm{kg}{ }^{-1}$ ) accumulated up to $1191 \mathrm{mg} \mathrm{kg} \mathrm{k}^{-1} \mathrm{Zn}$ in the roots, $3747 \mathrm{mg} \mathrm{kg}^{-1}$ in the stems and $3409 \mathrm{mg} \mathrm{kg}^{-1}$ in the leaves. S. nigrum plants grown in the same soil spiked with extra $\mathrm{Zn}$ (Zn levels of $964 \mathrm{mg} \mathrm{kg}^{-1}$ ) accumulated up to 4735,8267 and $7948 \mathrm{mg} \mathrm{Zn} \mathrm{kg}^{-1}$ in the leaves, stems and roots, respectively. The addition of EDTA promoted an increase in the concentration of $\mathrm{Zn}$ accumulated by $S$. nigrum of up to $231 \%$ in the leaves, $93 \%$ in the stems and $81 \%$ in the roots, while EDDS application enhanced the accumulation in leaves, stems and roots up to 140,124 and $104 \%$, respectively. In the stems, the presence of $\mathrm{Zn}$ was predominantly detected in the cortex collenchyma cells, the starch sheath and the internal phloem and xylem parenchyma, and the addition of chelating agents did not seem to have an effect on the localisation of accumulation sites. The devise of a chelate-enhanced phytoextraction strategy, using chelating agents and AMF, is discussed.
\end{abstract}

\section{Introduction}

The remediation of heavy metal contaminated soils is a challenging task due to the persistent characteristics of the elements, to which conventional technologies present costly and, sometimes, disturbing solutions. An emerging technology, phytoextraction - the use of plants to extract toxic com-

\footnotetext{
* Corresponding author. Tel.: +351 2255800 59; fax: +351 2250903 51.

E-mail addresses: amarques@mail.esb.ucp.pt (A.P.G.C. Marques), rsoliveira@mail.esb.ucp.pt (R.S. Oliveira), kas@ibmc.up.pt (K.A. Samardjieva), jpissarr@fc.up.pt (J. Pissarra), arangel@esb.ucp.pt (A.O.S.S. Rangel), plcastro@esb.ucp.pt (P.M.L. Castro).
}

pounds from soils (Blaylock and Huang, 2000) appears as a low cost and environmental-friendly solution for the remediation of soils contaminated with heavy metals. Although several conditions must be met for the adequate effectiveness of phytoextraction to be achieved, the bioavailability of metals to the plant root is considered to be a critical requirement for metal uptake to occur (Kayser et al., 2000). The addition of chelating agents can increase metal availability: the chelating agent complexes the free metal ion in solution, allowing further dissolution of the sorbed phase until an equilibrium between the free metal and the insoluble phases occurs (Norwell, 1991). Among the chelating agents used in studies of phytoextraction, EDTA has been the most widely cited because it is highly effective in mobilising metals in 
soils. Lai and Chen (2004) reported EDTA-enhanced Zn shoot uptake by Dianthus chinensis and Vetiver zizanoides grown in heavy metal contaminated soil. Brassica juncea has shown increased $\mathrm{Cu}$ accumulation when EDTA was applied to the growing matrix (Wu et al., 2004) and the same effect was reported for $\mathrm{Cd}$ and $\mathrm{Cr}$ uptake by Helianthus annus (Turgut et al., 2005). However, EDTA and EDTAheavy metals complexes can be toxic to plants and soil microorganisms, and can also persist in the environment due to their low level of biodegradability (Bucheli-Witschel and Egli, 2001; Grčman et al., 2003). The use of other chelating agents, such as EDDS, which is more readily biodegradable and constitutes a low toxic alternative to enhance the phytoextraction of heavy metals, has been proposed (Meers et al., 2005; Luo et al., 2006). As an example, Grčman et al. (2003) reported up to 4.7- and 3.5-fold EDDS-increased Zn and Cd uptakes in Brassica rapa.

Biotic factors also affect metal uptake by the plants. It is a generally held view that the majority of plants growing under natural conditions form symbiotic associations with arbuscular mycorrhizal fungi (AMF) which can enhance plant growth an improve plant reproduction (Smith and Read, 1997). The contribution of AMF to enhanced metal uptake and accumulation by plants in heavy metal contaminated sites has been reported (Joner and Leyval, 1997). The arbuscular mycorrhizal status changes the chemical composition of root exudates and influences soil $\mathrm{pH}$ (Citterio et al., 2005 ) - these factors, alone or in combination, can also influence metal mobility or availability, and thus, the potential of phytoextraction of metal contaminated soil can be enhanced by inoculating accumulator plants with the most appropriate AMF. Solanum nigrum (black nightshade) is an indigenous plant species to a metal polluted site in an industrialised area of Northern Portugal containing sediments with levels of metals above the limits established by European Council Directive 86/278/CEE of 12 June 1986, the main occurring metal in those sediments being zinc (Oliveira et al., 2001). Despite this contamination scenario, $S$. nigrum is abundant on the site (Marques et al., 2003). Previous studies with this plant showed that $S$. nigrum was able to accumulate up to $3800 \mathrm{mg} \mathrm{Zn} \mathrm{kg}{ }^{-1}$ dry tissue in the roots with no visible toxicity signs, and the inoculation with the AMF Glomus intraradices and Glomus claroideum contributed to an increase in $\mathrm{Zn}$ accumulation in plant tissues (Marques et al., 2006). In the present study, the influence of the addition of the chelating agents EDDS and EDTA, and their relationship with the presence of AMF isolates, on the bioavailability of $\mathrm{Zn}$ in contaminated soils, was assessed under greenhouse conditions. Metal uptake and $\mathrm{Zn}$ accumulation and localisation in S. nigrum is reported.

\section{Materials and methods}

\section{Soil preparation}

The soil used in this study was collected at a site located in Northern Portugal - Esteiro de Estarreja. The site is a small and almost stagnated watercourse, contaminated with the discharges of an adjacent wastewater conduct originating from the industrial complex that surrounds the area, and high levels of metal contamination, especially Zn, are present (Oliveira et al., 2001). Soil was collected randomly from the banks of the contaminated stream, to a $20 \mathrm{~cm}$ depth, in the dry season. The collected soil was sterilised at $120^{\circ} \mathrm{C}$ for $70 \mathrm{~min}$ in two consecutive days and dried in a drying oven at $40{ }^{\circ} \mathrm{C}$ for $4 \mathrm{~d}$.

In order to obtain more information on the behaviour of $S$. nigrum when exposed to higher toxicity, soil with a second level of $\mathrm{Zn}$ contamination was prepared by adding a solution of $\mathrm{ZnSO}_{4}$ to half of the mass of soil collected for the experiments, up to a concentration of 500 more $\mathrm{mg} \mathrm{Zn} \mathrm{kg} \mathrm{Zn}^{-1}$ dry soil. The portion of metal-treated soil was wetted for $1 \mathrm{wk}$ by adding deionised water to maintain $60 \%$ of the water holding capacity; the soil was then dried in the greenhouse for approximately $2 \mathrm{wk}$. This spiked soil was subjected to 3 cycles of wet and dry processes before amendments were added (Blaylock et al., 1997).

\section{Preparation of mycorrhizal inocula}

The two isolates of AMF used in this study have been isolated from heavy metal contaminated soils in central Europe and are in the AMF collection of the Department of Mycorrhizal Symbioses from the Institute of Botany, Academy of Sciences of the Czech Republic. Each of the two AMF isolates was individually grown in zeolite (clinoptilolite 1.0-2.5 mm, Chemko, Slovakia) for 12 months prior to the beginning of the experiment in multispore pot cultures with both Zea mays L. and Trifolium pratense $\mathrm{L}$. as host plants under the same greenhouse conditions. An inoculum suspension of each isolate was prepared by wet sieving $(710 \mathrm{~mm}) 450 \mathrm{~cm}^{3}$ of zeolite from pot cultures with deionised water to a final volume of $150 \mathrm{ml}$, and was used to inoculate the pots of each $\mathrm{Zn}$ treatment. Each pot of the mycorrhizal treatments received $10 \mathrm{ml}$ of the inoculum suspension containing colonised root fragments, hyphae and spores. The suspension was pipeted at $2 \mathrm{~cm}$ below the soil surface. Pots from control treatments received the same volume of the inoculum suspension autoclaved twice $\left(121^{\circ} \mathrm{C}\right.$ for $\left.25 \mathrm{~min}\right)$.

\section{Experimental design}

The experiment was a factorial design with two matrix $\mathrm{Zn}$ levels [contaminated soil from Estarreja (L) and the same soil spiked with extra $\mathrm{Zn}(\mathrm{L}+\mathrm{Zn})], 3$ chelating treatments (no agent, EDTA and EDDS) and 3 AMF treatments (no AMF, G. claroideum and G. intraradices). Each treatment was replicated five times.

Microbial populations from the local (L) soil were reintroduced to the equilibrated soil by adding $10 \mathrm{ml}$ of soil filtrate (Whatman No. 1) to each pot. The filtrate was obtained from $200 \mathrm{~g}$ of non-sterile local soil (L) shaken 
for $2 \mathrm{~h}$ in 21 of sterile deionised water (Oliveira et al., 2006).

Solanum nigrum L. (obtained from Instituto Botânico do Porto) seeds were surface sterilised with $0.5 \% \mathrm{NaOCl}$ for $10 \mathrm{~min}$ and were subsequently washed with sterilised water. Seeds were then germinated in the naturally contaminated Estarreja soil in the greenhouse. Three weeks after seeding, three equally developed seedlings were transplanted into plastic pots containing $300 \mathrm{~g}$ of each matrix. Pots were randomised on the greenhouse, process that was repeated every three weeks. Plants were maintained in a controlled growth room $(12 \mathrm{~h}$ photoperiod, $450 \mu \mathrm{mol} \mathrm{m}^{-2} \mathrm{~s}^{-1}$ photosynthetically active radiation, 18 $38{ }^{\circ} \mathrm{C}$ temperature range, $16-71 \%$ relative humidity range) and were watered daily. After S. nigrum had been grown for $23 \mathrm{wk}$, solutions of EDDS and EDTA were added at a rate of $0.5 \mathrm{~g} \mathrm{~kg}^{-1}$ soil to selected pots.

\section{Plant analyses}

Harvest was made $10 \mathrm{~d}$ after treatment with EDDS and EDTA. Plant roots were washed free of soil with deionised water. For assessing AMF colonisation, a sub-sample of fresh fine roots was collected from plants sampled at each pot (see below). For assessing $\mathrm{Zn}$ localisation, subsamples of stem tissue were taken and were prepared for autometallography (see below). Roots, stems and leaves of all the plants from each pot were separated, oven dried at $70{ }^{\circ} \mathrm{C}$ for $2 \mathrm{~d}$, after which biomass was determined by weighing the dried plant material from each pot.

For assessing AMF colonisation fresh fine root sub-samples were cut into approximately $1 \mathrm{~cm}$ pieces, heated in a pressure pan at $120^{\circ} \mathrm{C}$ in $10 \% \mathrm{KOH}$ and stained using an adaptation of the Phillips and Hayman (1970) protocol including a longer incubation in $2 \% \mathrm{HCl}$ (Oliveira et al., 2001). Stained root samples were examined under a stereomicroscope (Olympus, SZ60, Tokyo, Japan) to assess the percentage of mycorrhizal colonisation using the grid-line intersect method (Giovannetti and Mosse, 1980). For Zn content analysis, dried roots, stems and leaves were grinded and sieved to $<1 \mathrm{~mm}$. The resulting samples were then digested at high temperature (up to $205^{\circ} \mathrm{C}$ ) with a mixture of concentrated nitric, perchloric and sulphuric acids (40:4:1). Zinc content was determined using flame atomic absorption spectroscopy (FA-AAS) of the digests (Wallinga et al., 1989). BCR (Community Bureau of Reference) reference sample CRM 279 (sea lettuce) was analysed using the above-described total $\mathrm{Zn}$ determination analytical method. The value obtained by FA-AAS $\left(52.8 \pm 0.9 \mathrm{mg} \mathrm{Zn} \mathrm{kg}^{-1}\right.$ sample) confirmed the accuracy and precision of the method by comparison with the certified value $(51.3 \pm$ $1.2 \mathrm{mg} \mathrm{Zn} \mathrm{kg}^{-1}$ sample).

\section{Autometallography}

Autometallography was performed on subsamples of stems according to Heumann (2002), using $\mathrm{Na}_{2} \mathrm{~S}$ as $\mathrm{S}$ donor (Danscher and Montagnese, 1994). The samples were treated with osmium tetroxide (Heumann, 2002) and were embedded in epoxy Resin 812, according to the supplier's instructions. Semi-thin sections were prepared using a glass or diamond knife on an ultramicrotome (Supernova Reichert). Sections were always cut in a zone not deeper than $100 \mu \mathrm{m}$ from the surface of the stem piece. The sections were stained with saphranine and photographed on an Olympus BX50 microscope coupled to an Olympus DP50 digital camera.

\section{Soil analysis}

Samples from the soils to be used in the experiment were oven dried at $40{ }^{\circ} \mathrm{C}$ for $48 \mathrm{~h}$ and passed through a $1 \mathrm{~mm}$ sieve. Soil $\mathrm{pH}$, water content, organic matter content, total phosphorous $(\mathrm{P})$ and nitrogen $(\mathrm{N})$ were determined. The water (De Koe, 1994), EDTA extractable and ammonium acetate $\left(\mathrm{NH}_{4}-\mathrm{Ac}\right)$ extractable $\mathrm{Zn}$ fractions were determined, as well as the total $\mathrm{Zn}$ in the soil. All methods were based on Houba et al. (1995) and were previously described by Marques et al. (2007b). BCR reference sample CRM $141 \mathrm{R}$ (calcareous loam soil) was analysed through the above-referred total $\mathrm{Zn}$ determination analytical method. The value obtained by FA-AAS $\left(292.3 \pm 0.3 \mathrm{mg} \mathrm{Zn} \mathrm{kg}^{-1}\right.$ sample) confirmed the accuracy and precision of the method by comparison with the certified value (283 $\pm 5 \mathrm{mg} \mathrm{Zn} \mathrm{kg}^{-1}$ sample).

At the time of plant harvest, soil samples were collected from each pot and oven-dried at $40^{\circ} \mathrm{C}$ for $4 \mathrm{~d}$. After harvesting, the $\mathrm{Zn}$ in the remaining soils was extracted using deionised water, as explained above.

\section{Statistical analysis}

Statistical analysis was performed using the SPSS software program (SPSS Inc., Chicago, IL Version 12.0). The data were analysed by analysis of variance (ANOVA). To detect the statistical significance of differences $(P<0.05)$ between means, the Tukey test was performed.

\section{Chemicals}

The chemicals used were of analytical-grade and were obtained from Pronalab (liquid reagents), Merck (solid reagents), TAAB (epoxy resin 812) and Sigma (Trypan blue stain).

Results

\section{Soil properties}

Properties of the soil collected at the banks of Esteiro de Estarreja (L) and of the spiked soil $(\mathrm{L}+\mathrm{Zn})$ are given in Table 1 . The soils used in this study were slightly acidic and presented $\mathrm{Zn}$ levels of about $433 \mathrm{mg} \mathrm{Zn} \mathrm{kg} \mathrm{dry} \mathrm{soil,}^{-1}$, for the local soil, and $964 \mathrm{mg} \mathrm{Zn} \mathrm{kg}{ }^{-1}$ dry soil, after spiking 
Table 1

Soil properties

\begin{tabular}{|c|c|c|}
\hline & Local & $\begin{array}{l}\text { Local spiked with } \\
\text { extra } \mathrm{Zn}\end{array}$ \\
\hline $\mathrm{pH}$ & $5.02-5.12$ & $4.71-4.75$ \\
\hline Water content $(\%)$ & $3.0 \pm 0.7$ & $2.49 \pm 0.08$ \\
\hline Organic content $(\%)$ & $8.41 \pm 0.08$ & $8.30 \pm 0.07$ \\
\hline $\mathrm{N}\left(\mathrm{mg} \mathrm{kg}^{-1}\right)$ & $3962 \pm 42$ & $3791 \pm 336$ \\
\hline $\mathrm{P}\left(\mathrm{mg} \mathrm{kg}^{-1}\right.$ & $259 \pm 3$ & $221 \pm 11$ \\
\hline Total $\mathrm{Zn}\left(\mathrm{mg} \mathrm{kg}^{-1}\right)$ & $433 \pm 13$ & $964 \pm 42$ \\
\hline $\begin{array}{l}\text { EDTA extractable Zn } \\
\left(\mathrm{mg} \mathrm{kg}^{-1}\right)\end{array}$ & $179 \pm 20$ & $699 \pm 45$ \\
\hline $\begin{array}{l}\mathrm{NH}_{4}-\mathrm{Ac} \text { extractable } \mathrm{Zn} \\
\quad\left(\mathrm{mg} \mathrm{kg}^{-1}\right)\end{array}$ & $69 \pm 42$ & $391 \pm 12$ \\
\hline $\mathrm{H}_{2} \mathrm{O}$ extractable $\mathrm{Zn}\left(\mathrm{mg} \mathrm{kg}^{-1}\right)$ & $30 \pm 7$ & $266 \pm 14$ \\
\hline
\end{tabular}

$\mathrm{pH}$ is expressed as a range. Other results are expressed as means $\pm \mathrm{SD}$ $(n=3)$. Further properties of the local soil have been described in Marques et al. (2007a) and Oliveira et al. (2001).

with $\mathrm{Zn}$. The $\mathrm{Zn}$ contents extractable by EDTA, $\mathrm{NH}_{4}-\mathrm{Ac}$ and $\mathrm{H}_{2} \mathrm{O}$ represent 41,16 and $7 \%$ of the total for local (L) soil and 73, 41 and $28 \%$ of the total for the extra- $\mathrm{Zn}$ spiked soil $(\mathrm{L}+\mathrm{Zn})$, respectively.

\section{Mycorrhizal colonisation}

No AMF colonisation was found in the non-inoculated control treatments. Addition of either EDDS or EDTA affected the mycorrhizal status of the plant, for both $\mathrm{Zn}$ levels in the matrix ( $\mathrm{L}$ and $\mathrm{L}+\mathrm{Zn}$ ). In general, the application of both chelating agents, especially EDTA, induced a significant decrease on plant colonisation by both AMF (Fig. 1).

The increase in the $\mathrm{Zn}$ level in the soil also had a significant negative effect in the percentage colonisation by both G. claroideum and G. intraradices (Fig. 1).

\section{Plant Biomass}

Roots of $S$. nigrum plants grown with the highest $\mathrm{Zn}$ level $(\mathrm{L}+\mathrm{Zn})$ presented lower biomass yields than plants grown in the local soil (L) (Table 2). Generally, inoculation with the AMF isolates affected significantly the biomass of all of the sections of $S$. nigrum when growth was made in any of the contaminated soils, either by promoting an increase or a decrease in the biomass of the plant, but with no evident trend in these effects (Table 2).

Before the treatment with EDTA or EDDS, all the plants showed no visual toxicity signs. The application of both EDTA and EDDS to the contaminated soils had no significant effect in the biomass of $S$. nigrum (Table 2) but signs of toxicity appeared, especially in the EDTA treated plants - visual chlorosis and necrosis of leaves.

\section{EDTA and EDDS effect on Zn water-extractable}

The concentrations of water-soluble $\mathrm{Zn}$ in the soils were examined to assess the efficiency of EDTA and EDDS in enhancing metal solubilisation. The $\mathrm{Zn}$ concentrations in water-extracts of the soils collected at the time of harvest were significantly increased by the addition of EDTA or EDDS to either of the contaminated soils, by up to 4.0and 3.1-folds, respectively. In some cases, the addition of EDTA has shown to be more efficient than EDDS increasing significantly $(P<0.05)$ the soluble $\mathrm{Zn}$ (Fig. 2).

The effect of the inoculation with AMF was also investigated. An increase in the levels of $Z n$ in the water extracts of the extra-Zn spiked soil $(\mathrm{L}+\mathrm{Zn})$ when EDTA or EDDS were applied was only observed when $S$. nigrum had been inoculated with $G$. intraradices.

\section{Zn concentration in the plant}

Tissues of plants grown in the soil with higher $\mathrm{Zn}$ levels $(\mathrm{L}+\mathrm{Zn})$ always presented higher $\mathrm{Zn}$ levels, showing an influence of the $\mathrm{Zn}$ levels in the matrix in the plant uptake and accumulation. S. nigrum plants grown in the local soil (L) accumulated up to $3409 \mathrm{mg} \mathrm{kg}^{-1}$ of $\mathrm{Zn}$ in the roots, $3747 \mathrm{mg} \mathrm{kg}^{-1}$ in the stems and $1191 \mathrm{mg} \mathrm{kg}^{-1}$ in the leaves; plants grown in the extra- $\mathrm{Zn}$ spiked local soil $(\mathrm{L}+\mathrm{Zn})$ accumulated up to 7948,8267 and $4735 \mathrm{mg} \mathrm{Zn} \mathrm{kg}^{-1}$ in the roots, stems and leaves, respectively, with the higher uptakes being registered for chelating agents treated plants (Table 3).

The inoculation with AMF had a positive effect on the accumulation of $\mathrm{Zn}$ in $S$. nigrum plants grown in the local soil, with both G. claroideum and G. intraradices inducing significantly higher $\mathrm{Zn}$ accumulations in all the plant sections when comparing with non-inoculated plants (Table $3)$. When the local soil (L) was treated with EDDS or EDTA, the effect of AMF on $\mathrm{Zn}$ accumulation in the roots, stems and leaves of $S$. nigrum was always significant, with inoculated plants presenting higher accumulations in these sections. An exception was observed for the accumulations registered for the stems and roots of $S$. nigrum grown in EDDS treated soil, in which no effect of the AMF inoculation was seen. For $S$. nigrum plants growing in extra- $Z n$ spiked soil $(\mathrm{L}+\mathrm{Zn})$, the inoculation with $G$. intraradices and G. claroideum led to significantly higher $\mathrm{Zn}$ accumulation in the leaves when no chelating agent was added, and to significantly $(P<0.05)$ lower or similar $\mathrm{Zn}$ accumulations in plants growing in the EDTA or EDDS treated soils (Table 3).

Furthermore, the chelating agents addition to the soil also increased significantly $\mathrm{Zn}$ accumulation in the roots, stems and leaves of $S$. nigrum. The highest $\mathrm{Zn}$ accumulations were registered for plants that were grown in substrates that received EDDS or EDTA. An exception was observed for the roots of $S$. nigrum plants grown in extra- $\mathrm{Zn}$ spiked soil $(\mathrm{L}+\mathrm{Zn})$, for which the application of the chelating agents had no effect on the metal accumulation in this plant section, as shown by the results of twoway ANOVA (Table 3). S. nigrum uptake of $\mathrm{Zn}$ was thus generally increased by the addition of EDTA or EDDS, 

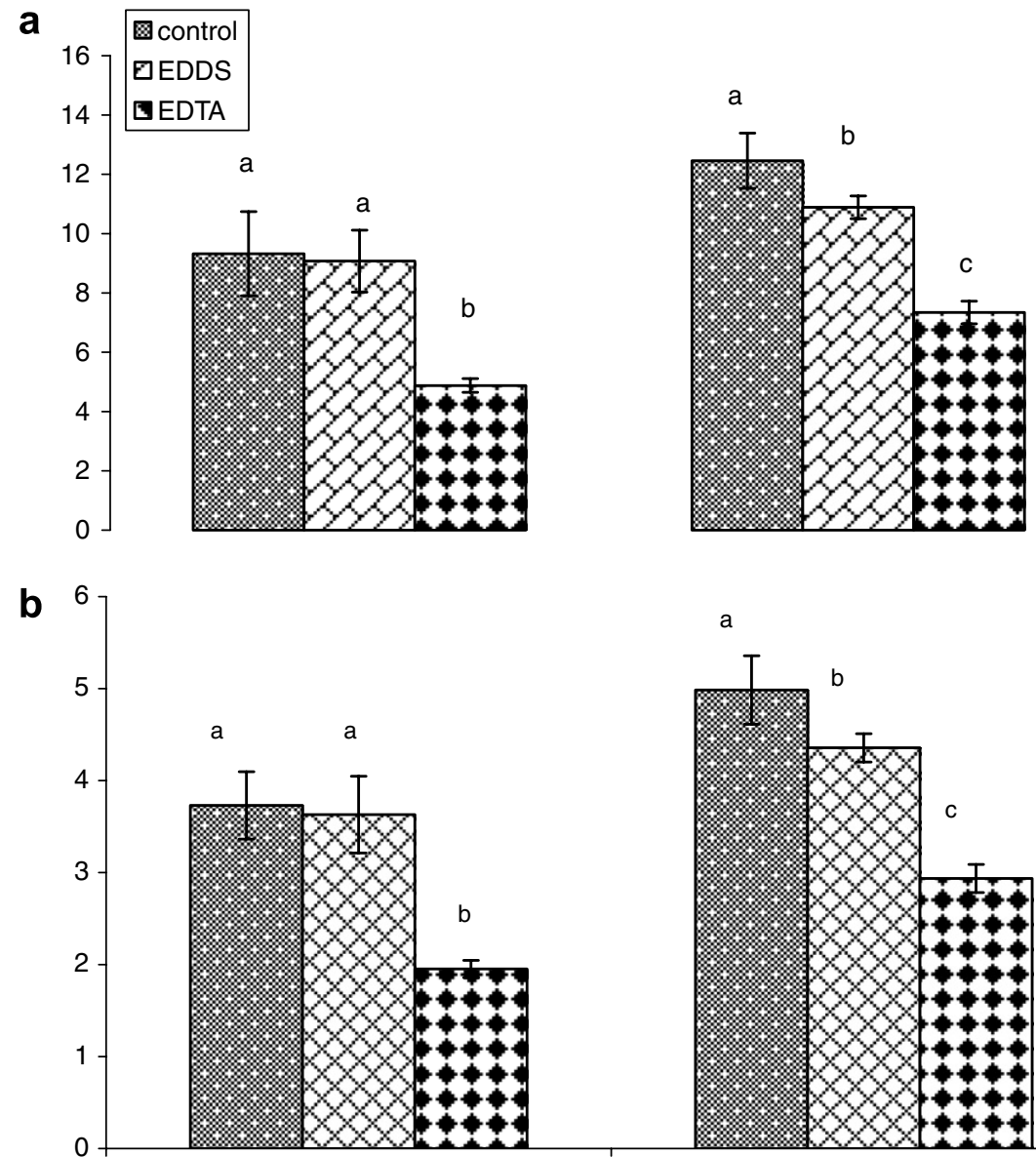

G. claroideum

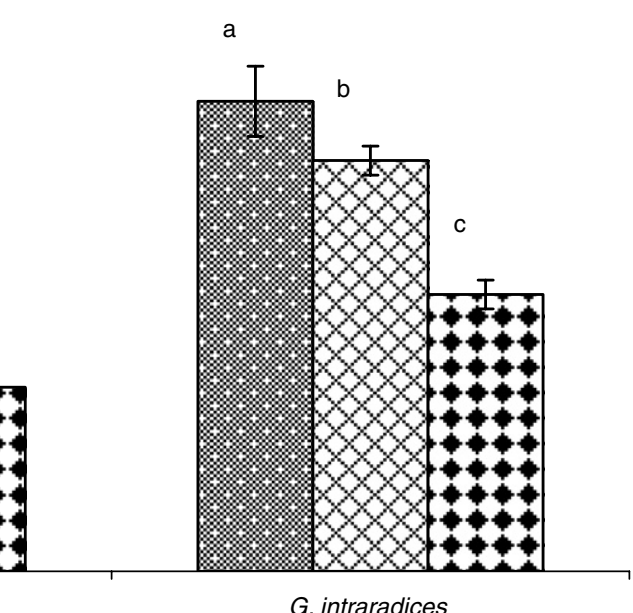

Fig. 1. Percentage of mycorrhizal colonisation for G. claroideum and G. intraradices in S. nigrum grown in local soil (a) and extra-Zn spiked soil (b). Results are expressed as percentual means. The error bars represent the SD. Means with different letters for the same AMF species within each soil are significantly different from each other $(P<0.05)$ according to the Tukey test.

with no significant differences between both chelating agents (Table 3).

\section{Root to aboveground parts translocation}

The translocation factors (TFs) were determined for the different treatments (Fig. 3). Higher Zn levels in the soil induced higher translocation rates in S. nigrum. These values were determined using the ratio $\left\{\left([\mathrm{Zn}]_{\text {stems }} * \mathrm{~A}+\right.\right.$ $\left.\left.[\mathrm{Zn}]_{\text {leaves }} * \mathrm{~B}\right) /\left([\mathrm{Zn}]_{\text {roots }} * \mathrm{C}\right)\right\}$ where $\mathrm{A}, \mathrm{B}$ and $\mathrm{C}$ are biomass of stems, leaves and roots, respectively (Marques et al., 2006).

The analysis of the TFs of $S$. nigrum inoculated with each of the AMF species showed that the addition of chelating agents only had a significant effect when higher levels of $\mathrm{Zn}$ contamination were present in the soil $(\mathrm{L}+\mathrm{Zn}$ soil), and in non-inoculated control plants. With these exceptions, neither EDTA nor EDDS had an effect on the root to shoot $\mathrm{Zn}$ translocation in $S$. nigrum under these conditions. In fact, when assessing the global effect of the chelating agent treatments and of the inoculation with AMF in the TFs, it was observed that none of these factors had a significant $(P<0.05)$ impact on the translocation rates.
Percentage of $\mathrm{Zn}$ uptake to the plant shoots from the soil

The percentage of $\mathrm{Zn}$ taken up by $S$. nigrum shoots relatively to the total $\mathrm{Zn}$ initially present in the pots is presented in Fig. 4. For the local soil (L), the treatment that better enhanced the percentage of uptake of $\mathrm{Zn}$ to the aboveground tissues of $S$. nigrum was the combination of the inoculation with $G$. claroideum with the addition of EDTA; for the extra-Zn spiked soil, the treatments that led to higher phytoextraction capabilities of the plant were the combination of the inoculation with $G$. intraradices with the addition of EDTA, and also the application of EDDS alone.

\section{Zn localization on stems of S.nigrum}

Zinc localization was determined on stem samples (control, EDTA and EDDS treated soils) by autometalography and no differences were found between treatments. In all cases, dark staining resulting from the metal presence were visible in all the tissues with predominance to the cortex collenchyma cells (Fig. 5A and Fig. 6A). Dark granules indicative of $\mathrm{Zn}$ were mainly found in the protoplasm 
Table 2

Effects of the addition of chelating agents and AMF species on S. nigrum biomass

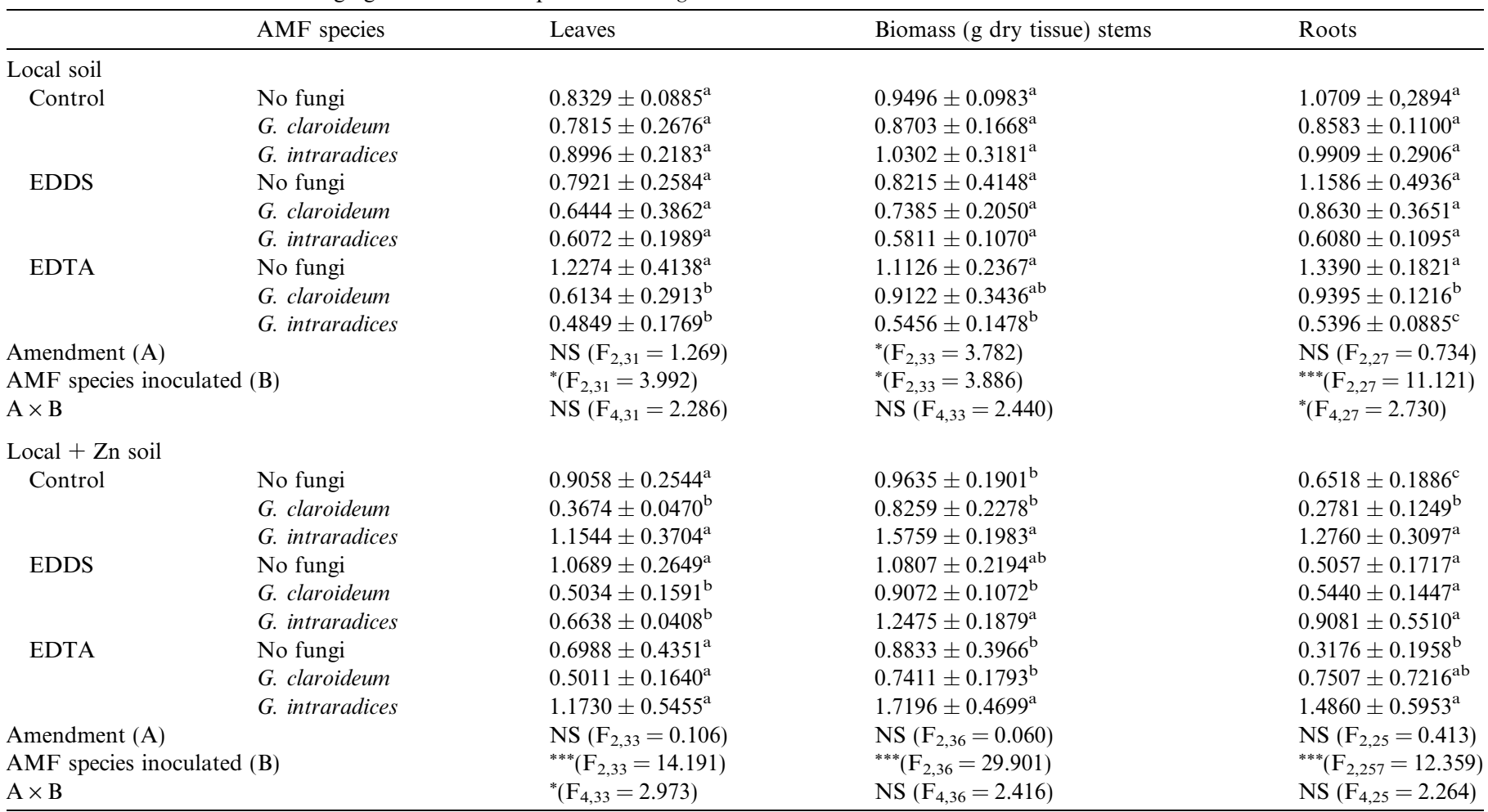

One-way ANOVA was performed for each chelating treatment. Means in the same treatment group with different letters are significantly different from each other $(P<0.05)$ according to the Tukey test.

Two-way ANOVA was performed to determine the influence of AMF and of chelators addition to each soil. The test results are shown with the test statistic and as: NS - Non significant at the level $P<0.05 ;^{*}, * * *$ Significant at the level $P<0.05$ and $P<0.001$, respectively.

(Fig. 5A - arrows). In Fig. 5B, showing a stoma and air chamber, $\mathrm{Zn}$ was found inside all the cells; outside the cells $\mathrm{Zn}$ was only found in the air chamber of the stoma. The starch sheath, typical of this type of stem structure, is one of the main $\mathrm{Zn}$ accumulation sites (Fig. 5C and D, arrows). As shown in Fig. 5E and $\mathrm{F}$ the medullar parenchyma is not a $\mathrm{Zn}$ accumulation site. On the other hand, the inner phloem and associated parenchyma as well as the parenchyma of the primary xylem (proto and metaxylem) show a high density of dark particles indicating intense accumulation of $\mathrm{Zn}$ in these structures (Fig. 5G, H and Fig. 6A).

\section{Discussion}

The soils used in the current study presented $\mathrm{Zn}$ levels similar or higher than those established as toxic to plants. According to Kabata-Pendias and Pendias (1984) - a total fraction of $400 \mathrm{mg} \mathrm{kg}^{-1} \mathrm{Zn}$ in the soil would already be considered as phytotoxic. In addition, the $\mathrm{Zn}$ contents extractable by EDTA, potentially available for plant uptake, represent a significant portion of the total $\mathrm{Zn}$ present in the soils. Therefore, the levels of $\mathrm{Zn}$ would normally impose toxic effects on plant growth, especially in the $\mathrm{Zn}$ spiked soil $(\mathrm{L}+\mathrm{Zn})$, inhibiting root vitality and plant growth, and preventing the absorption of inorganic nutrients (Borregard and Rydin, 1989). Although no signs of
Zn excess were visible in the plants grown in the present study, when no chelating agents were added to the soils, the $\mathrm{Zn}$ level in the soil affected the behaviour of the plant-AMF associations. The increase in the $Z n$ level in the soil (from $\mathrm{L}$ to $\mathrm{L}+\mathrm{Zn}$ ) promoted a reduction in the colonisation by AMF. A similar trend has been reported by Marques et al. (2006), who observed a reduced colonisation of $S$. nigrum by different AMF ( $G$. sp. BEG140, $G$. claroideum, G. mosseae, and G. intraradices), when grown in sand spiked with high $\mathrm{Zn}$ levels. Citterio et al. (2005) have also reported this negative effect on mycorrhizal colonisation of Cannabis sativa as a consequence of the addition of heavy metals to the growing matrix. In addition, plants growing in the highly contaminated soil $(\mathrm{L}+\mathrm{Zn})$ accumulated higher levels of $\mathrm{Zn}$ in their roots, stem and leaves, and presented a reduction in their biomass. The $\mathrm{Zn}$ levels for all the sections of $S$. nigrum registered in this study are above those considered as phytotoxic for plants according to Chaney (1989) -500 to $1500 \mathrm{mg} \mathrm{kg}^{-1}$. The possible increase in biomass formation promoted by the inoculation with AMF could be a means to compensate the depletion of biomass production due to the stress caused by $\mathrm{Zn}$ presence in the matrix. However, this was not observed in this study. Only in some cases the biomass of $S$. nigrum was improved when AMF were present, while in other cases no enhancement, or even a decrease, in the 

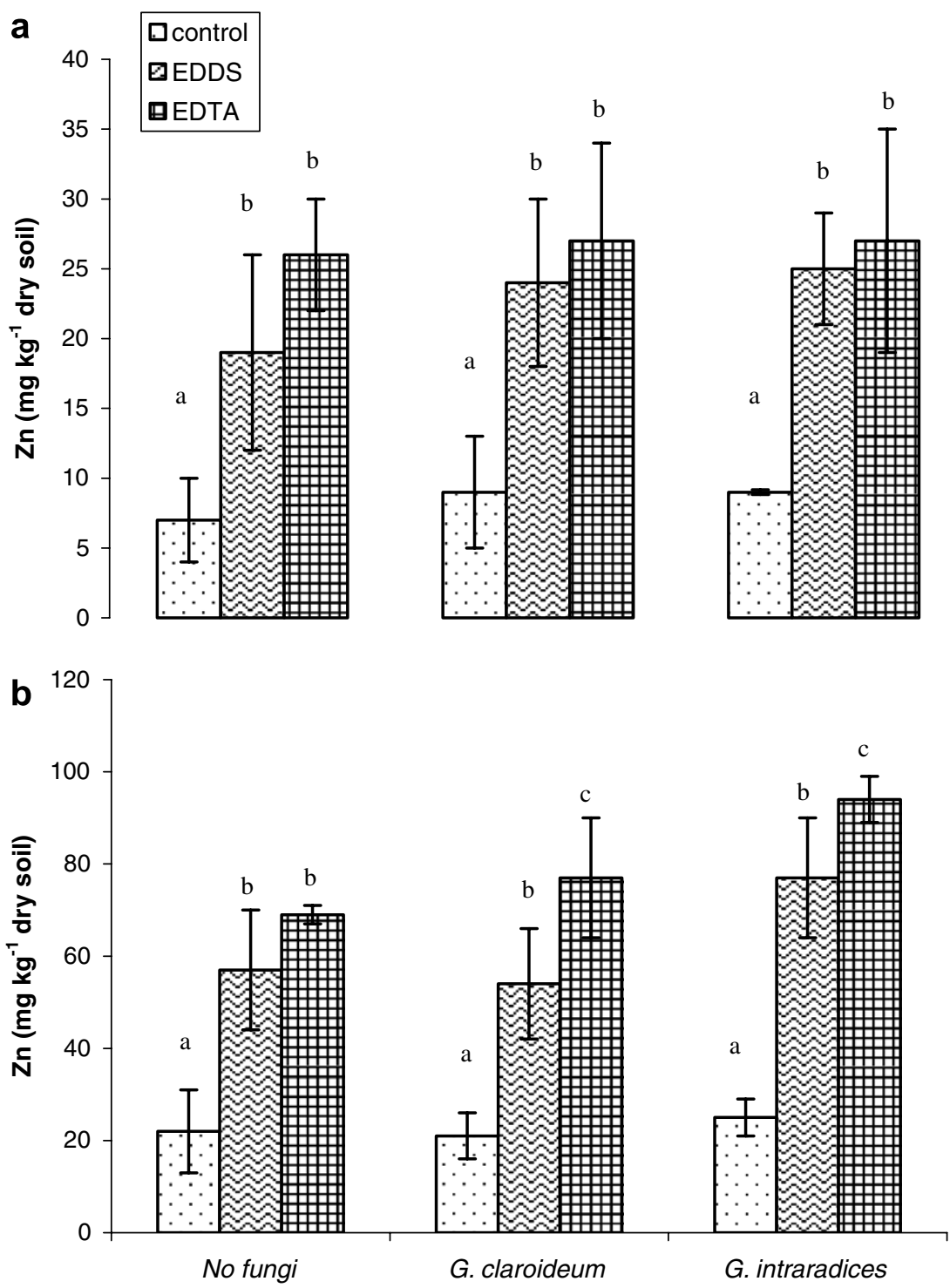

Fig. 2. Effects of the addition of chelating agents on the $\mathrm{Zn}$ availability in local soil (a) and in extra-Zn spiked soil (b). Results are expressed as means. The error bars represent the SD. Means with different letters for the same AMF treatments within each soil are significantly different from each other $(P<0.05)$ according to the Tukey test.

biomass of the different plant sections occurred. In fact, although the relationships between plants and AMF are generally reported as mutualistic (Smith and Read, 1997), with most studies reporting enhanced plant growth with mycorrhizal colonisation (Chen et al., 2005), negative (Johnson et al., 1997) or even neutral (Marques et al., 2006) plant responses have been observed, under certain environmental conditions. Nevertheless, it seems that $S$. nigrum inoculated with these AMF has the potential to grow and accumulate $\mathrm{Zn}$ in $\mathrm{Zn}$ contaminated sites. The growth of this species occurred even in soils with $\mathrm{Zn}$ levels as those registered for the extra-Zn spiked soil $(\mathrm{L}+\mathrm{Zn})$. It seems that the AMF protected the plant of excessive $\mathrm{Zn}$, which is translated in a decrease in metal accumulation in AMF inoculated plants (Göhre and Paszkowski, 2006). On the other hand, there was an increase in the metal accu- mulation when $\mathrm{Zn}$ levels in the growing matrix were lower suggesting that this plant-AMF association can enhance the accumulation abilities demonstrated by the plant alone. Similar tendencies were reported by Diaz et al. (1996) for the uptake of $\mathrm{Zn}$ and $\mathrm{Pb}$ by Lygeum spartum and Anthylis cytisoides inoculated with G. mosseae in soils with different levels of theses metals: at low doses, mycorrhizal plants had equal or higher $\mathrm{Zn}$ or $\mathrm{Pb}$ concentrations than non-inoculated controls; at higher doses, however, metal concentrations in the plants inoculated with $G$. mosseae were lower than those found in the corresponding controls.

For both $\mathrm{Zn}$ contaminated soils, the addition of EDTA promoted a decrease in the root colonisation of $S$. nigrum by both $G$. claroideum and $G$. intraradices, reducing the colonisation to significantly lower levels than the ones registered for plants growing in the EDDS or in the non-treated 
Table 3

Effects of the addition of chelating agents and AMF species on S. nigrum Zn accumulation

\begin{tabular}{|c|c|c|c|c|}
\hline & AMF species & Leaves & $\mathrm{Zn}\left(\mathrm{mg} \mathrm{kg}^{-1}\right.$ dry tissue) stems & Roots \\
\hline \multicolumn{5}{|l|}{ Local soil } \\
\hline \multirow[t]{3}{*}{ Control } & No fungi & $531 \pm 21^{\mathrm{c}}$ & $1431 \pm 57^{\mathrm{c}}$ & $1356 \pm 359^{\mathrm{c}}$ \\
\hline & G. claroideum & $656 \pm 35^{\mathrm{b}}$ & $1938 \pm 134^{\mathrm{b}}$ & $1798 \pm 148^{\mathrm{b}}$ \\
\hline & G. intraradices & $851 \pm 69^{a}$ & $2482 \pm 40^{\mathrm{a}}$ & $2687 \pm 49^{\mathrm{a}}$ \\
\hline \multirow[t]{3}{*}{ EDDS } & No fungi & $764 \pm 55^{\mathrm{b}}$ & $3068 \pm 615^{\mathrm{a}}$ & $2769 \pm 541^{\mathrm{a}}$ \\
\hline & G. claroideum & $1016 \pm 20^{\mathrm{a}}$ & $2855 \pm 343^{\mathrm{a}}$ & $3409 \pm 561^{\mathrm{a}}$ \\
\hline & G. intraradices & $1020 \pm 52^{\mathrm{a}}$ & $2899 \pm 205^{\mathrm{a}}$ & $3095 \pm 40^{\mathrm{a}}$ \\
\hline \multirow[t]{3}{*}{ EDTA } & No fungi & $506 \pm 55^{\mathrm{b}}$ & $2190 \pm 293^{\mathrm{b}}$ & $2461 \pm 343^{\mathrm{b}}$ \\
\hline & G. claroideum & $1191 \pm 214^{\mathrm{a}}$ & $3747 \pm 912^{\mathrm{a}}$ & $3069 \pm 58^{\mathrm{a}}$ \\
\hline & G. intraradices & $978 \pm 108^{\mathrm{a}}$ & $2809 \pm 183^{\mathrm{ab}}$ & $3150 \pm 277^{\mathrm{a}}$ \\
\hline \multicolumn{2}{|c|}{ Amendment (A) } & ${ }^{* * *}\left(\mathrm{~F}_{2,31}=29.964\right)$ & $* * *\left(\mathrm{~F}_{2,34}=25.835\right)$ & ${ }^{* * *}\left(\mathrm{~F}_{2,25}=43.999\right)$ \\
\hline \multicolumn{2}{|c|}{ AMF species inoculated (B) } & ${ }^{* * *}\left(\mathrm{~F}_{2,31}=62.139\right)$ & ${ }^{* * *}\left(\mathrm{~F}_{2,34} \mathrm{~V} 8.710\right)$ & ${ }^{* * *}\left(\mathrm{~F}_{2,25}=17.887\right)$ \\
\hline \multicolumn{2}{|c|}{$\mathrm{A} \times \mathrm{B}$} & ${ }^{* * *}\left(\mathrm{~F}_{4,31}=12.895\right)$ & ${ }^{* * *}\left(\mathrm{~F}_{4,34}=7.668\right)$ & ${ }^{* * *}\left(\mathrm{~F}_{4,25}=4.442\right)$ \\
\hline \multicolumn{5}{|c|}{ Local $+\mathrm{Zn}$ soil } \\
\hline \multirow[t]{3}{*}{ Control } & No fungi & $1434 \pm 161^{\mathrm{b}}$ & $3690 \pm 441^{\mathrm{b}}$ & $5628 \pm 388^{\mathrm{a}}$ \\
\hline & G. claroideum & $2542 \pm 525^{\mathrm{a}}$ & $5446 \pm 490^{\mathrm{a}}$ & $7465 \pm 1662^{\mathrm{a}}$ \\
\hline & G. intraradices & $2082 \pm 180^{\mathrm{a}}$ & $4423 \pm 464^{\mathrm{b}}$ & $6399 \pm 429^{\mathrm{a}}$ \\
\hline \multirow[t]{3}{*}{ EDDS } & No fungi & $3435 \pm 455^{\mathrm{a}}$ & $8267 \pm 1250^{\mathrm{a}}$ & $6463 \pm 83^{\mathrm{a}}$ \\
\hline & G. claroideum & $3627 \pm 228^{a}$ & $7317 \pm 439^{\mathrm{a}}$ & $7363 \pm 150^{\mathrm{a}}$ \\
\hline & G. intraradices & $3221 \pm 84^{\mathrm{a}}$ & $4787 \pm 501^{\mathrm{b}}$ & $7140 \pm 997^{\mathrm{a}}$ \\
\hline \multirow[t]{3}{*}{ EDTA } & No fungi & $4735 \pm 480^{\mathrm{a}}$ & $7028 \pm 414^{\mathrm{a}}$ & $7948 \pm 514^{\mathrm{a}}$ \\
\hline & G. claroideum & $3444 \pm 430^{\mathrm{b}}$ & $6236 \pm 415^{\mathrm{b}}$ & $6953 \pm 53^{\mathrm{b}}$ \\
\hline & G. intraradices & $3070 \pm 248^{b}$ & $6474 \pm 215^{\mathrm{ab}}$ & $6816 \pm 359^{\mathrm{b}}$ \\
\hline \multicolumn{2}{|c|}{ Amendment (A) } & ${ }^{* * *}\left(\mathrm{~F}_{2,3} 1=102.573\right)$ & ${ }^{* * *}\left(\mathrm{~F}_{2,35}=68.144\right)$ & $\mathrm{NS}\left(\mathrm{F}_{2,24}=2.166\right)$ \\
\hline \multicolumn{2}{|c|}{ AMF species inoculated (B) } & ${ }^{* *}\left(\mathrm{~F}_{2,31}=6.354\right)$ & $* * *\left(\mathrm{~F}_{2,35}=17.481\right)$ & $\mathrm{NS}\left(\mathrm{F}_{2,24}=1.396\right)$ \\
\hline \multicolumn{2}{|c|}{$\mathrm{A} \times \mathrm{B}$} & ${ }^{* * *}\left(\mathrm{~F}_{4,31}=18.298\right)$ & ${ }^{* * *}\left(\mathrm{~F}_{4,35}=21.173\right)$ & ${ }^{*}\left(\mathrm{~F}_{4,24}=3.004\right)$ \\
\hline
\end{tabular}

One-way ANOVA was performed for each chelating treatment. Means in the same treatment group with different letters are significantly different from each other $(P<0.05)$ according to the Tukey test.

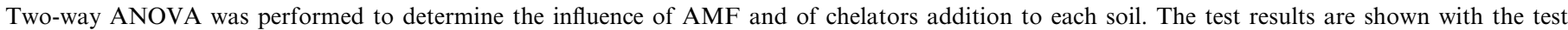
statistic and as: NS - Non significant at the level $P<0.05 ;{ }^{*} *^{* *} * * *$ Significant at the level $P<0.05, P<0.01$ and $P<0.001$, respectively.

soils. Other reports have shown similar results: Grčman et al. (2003) reported that EDTA addition to a metal contaminated soil induced fungi stress; Chen et al. (2004) indicated lower AMF colonisation of $Z$. mays when grown in EDTA treated soil. On the other hand, the addition of EDTA had no effect on the biomass formation of $S$. nigrum in the present study, probably due to the late addition of the chelating agents, not allowing the effect of this addition to be translated in significant differences in the growth of treated and not treated plants. Other studies reported the same effect demonstrating that the late addition of the chelating agents avoids loss of potential plant development. Wu et al. (2004) reported no influence of EDTA application to the soil at a rate of $3 \mathrm{mmol} \mathrm{kg}^{-1}$ in the biomass yield of B. juncea and Meers et al. (2005) reported that the addition of up to $4 \mathrm{mmol} \mathrm{kg}{ }^{-1}$ EDTA had no influence on the biomass production of Helianthus annuus.

The soil treatment with EDTA led to an increase in the water extractable fraction of $\mathrm{Zn}$, as has also been described in other reports (Lai and Chen, 2004; Luo et al., 2004). The concentration of metal extracted using deionised water can be considered equal to the water soluble form in the contaminated soil that is easily leached into the groundwater along with possible rainfall (Lai and Chen, 2004) and easily taken up by plants. This was also observed in the present study, as $\mathrm{Zn}$ accumulation by $S$. nigrum increased when EDTA was added to the growing matrix.
The addition of EDDS to the contaminated soil promoted a reduction in the root colonisation of $S$. nigrum by both $G$. claroideum and $G$. intraradices. Sudová et al. (2007) also reported a reduced AMF colonisation of Nicotiana tabacum, another plant from the Solanaceae family, when growing in EDDS treated soil. However, EDDS induced significantly lower reductions in the colonisation by both AMF than EDTA. Grčman et al. (2003) reported that EDDS addition to a metal contaminated soil induced earlier fungi stress; however, EDDS toxicity was revealed much later than EDTA-induced stress. EDDS is a naturally occurring aminopolycarboxylic acid, produced by a number of microorganisms (Goodfellow et al., 1997) and this is the likely reason for its lower toxicity.

The application of EDDS resulted in lower Zn availability in the water extracts, suggesting that the addition of EDDS appears as a less dangerous solution than applying EDTA, which can increase the danger of further metal leaching and groundwater contamination. Enhanced phytoextraction is more feasible if fewer disturbances are applied to the contaminated site, and fewer risks of possible transference from soil to other environmental compartments are taken. EDTA and its complexes are known for being poorly photo-, chemo- and biodegradable in soil environments (Nörtemann, 1999), with a minimum observed half-life of ca. 36 d (Meers et al., 2005): its longevity will cause higher metal mobility, even long after harvest, 

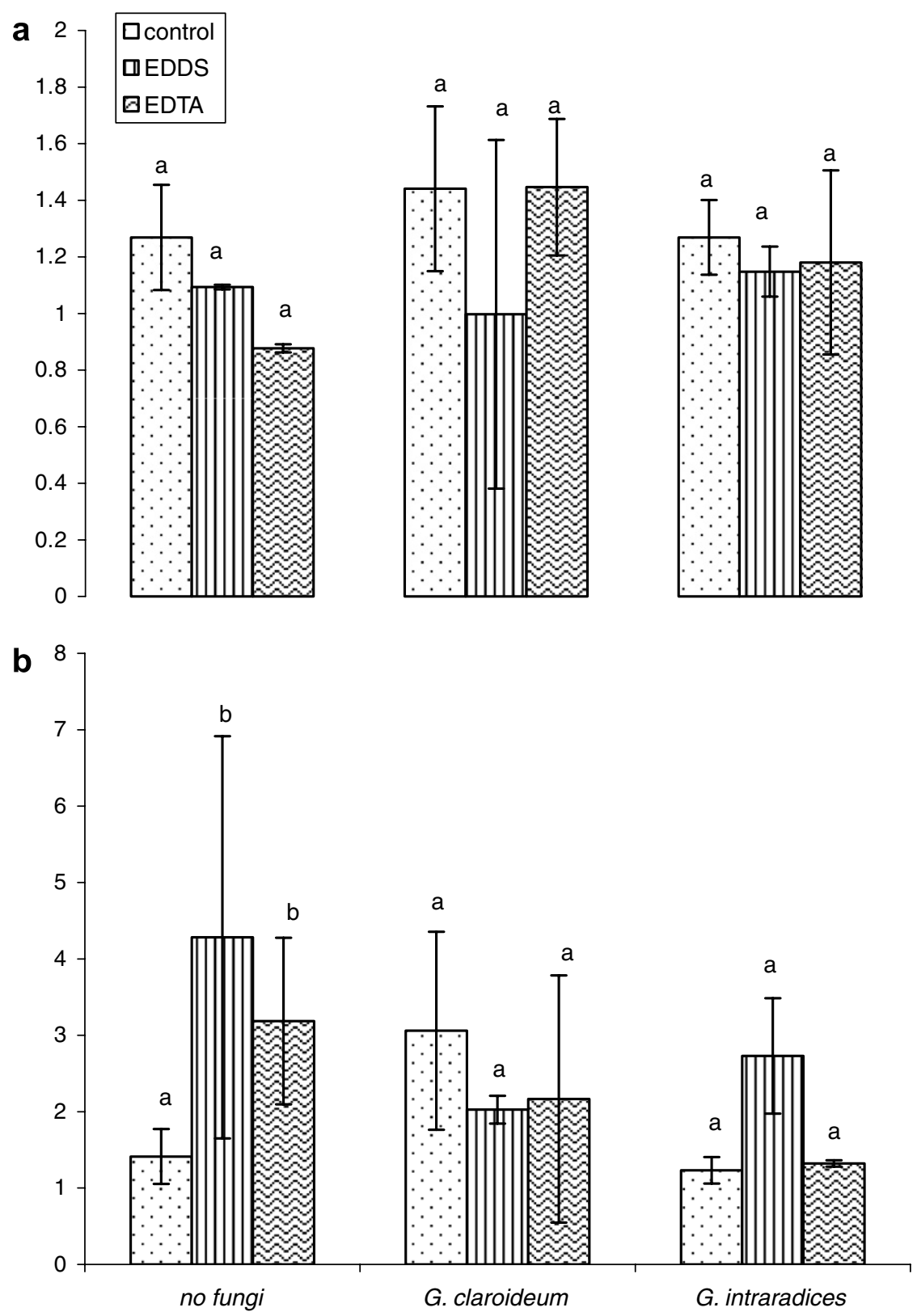

Fig. 3. Translocation factor of S. nigrum for different AMF treatments in local soil (a) and in extra-Zn spiked soil (b). Results are expressed as means. The error bars represent the SD. Means with different letters for the same AMF treatments within each soil are significantly different from each other $(P<0.05)$ according to the Tukey test.

implying leaching of metals and an increased risk of contamination of the groundwater. On the other hand, EDDS half-life is reported as ca. $2.5 \mathrm{~d}$ in soil, achieving complete mineralisation in $28 \mathrm{~d}$ (Schowanek et al., 1997). Nevertheless, the addition of EDDS enhanced $\mathrm{Zn}$ accumulation in a similar way to EDTA. Other studies have reported a neutral effect of EDDS addition in the growth of $B$. rapa and $H$. annuus, respectively (Grčman et al., 2003; Meers et al., 2005). These reports also indicate that the rates of metal uptake enhancement by EDDS addition were similar to the enhancement of those obtained when EDTA was added to the growing matrix.

The objectives of phytoextraction include the extraction of metals into bioavailable forms that can be taken up by plants and the enhancement of metal translocation from roots to shoots (Huang et al., 1997). While chelating agents have been proven to be successful at increasing metal bioavailability through enhancing metal solubility, their possible success at overcoming the barrier root to shoot (stems and leaves) translocation is not well documented (Lombi et al., 2001). Therefore, in addition to evaluating a chelating agent's effectiveness at mobilising the metals to the root zone, and understanding its effects on plant biomass and accumulation, the extent of translocation to the shoots is an important factor for the choice of a phytoextraction strategy. Few studies focused on the translocation variations imposed by the addition of chelating agents. Luo et al. (2004) have reported that the application of EDTA 

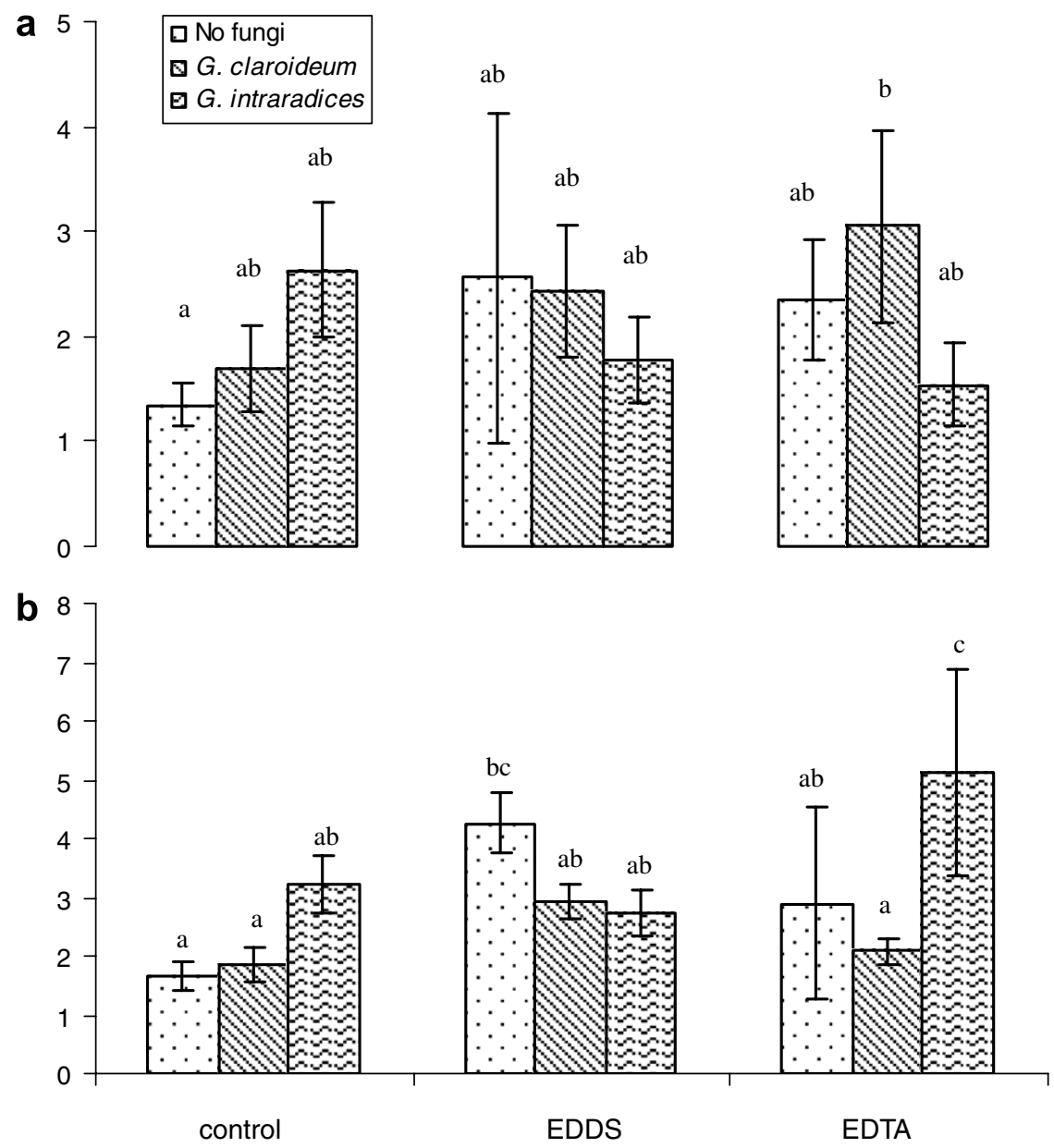

Fig. 4. Percentage of $\mathrm{Zn}$ uptake to the plant shoots from the local soil (a) and extra-Zn spiked soil (b). Results are expressed as percentual means. The error bars represent the SD. Means with different letters within each soil are significantly different from each other $(P<0.05)$ according to the Tukey test.

and EDDS increases the root-to-shoot ratios of the metals $\mathrm{Cu}, \mathrm{Pb}, \mathrm{Zn}$ and $\mathrm{Cd}$ in $\mathrm{Z}$. mays and Phaseolus vulgaris, but that was not observed in the present study. Despite the enhancement of $\mathrm{Zn}$ accumulation by $S$. nigrum shoots (stem + leaves) in the EDTA and EDDS treatments, no effect of the chelating agents was translated in enhanced translocation of the metals to the aboveground parts of the plants, as the chelate-increased solubilisation of $\mathrm{Zn}$ in the soils induced higher accumulations not only in the shoots but also in the roots of $S$. nigrum. Autometallography was performed on stem samples with no AMF inoculation, as it has been reported in previous studies (Marques et al., 2007a) that the inoculation with AMF had not effect on the pattern of localisation of the metal in the plant tissues. In the present study, and for all treatments, $\mathrm{Zn}$ was located predominantly in the collenchyma of the cortex, the starch sheath and also internal phloem and xylem parenchyma. As the metal is translocated through the plant, it is unloaded into the vascular parenchyma. Since the stem of $S$. nigrum has stomata, the xylem sap (water and other materials) is transported from the vascular parenchyma to the outer zones of the stem. One barrier in this direction is the starch sheath, another site of $\mathrm{Zn}$ accumulation pointed out earlier. Substances may then be transported to the outer cortex and may be carried out into the stoma air chamber. The stems of the plant are not excluding the metal from inside the cells, pattern that was observed for all treatments and thus is not an effect of the addition of chelating agents (Fig. 5 and 6), that in fact are not affecting the localisation of accumulation sites in the plant stem tissues.

When analysing the percentage of $\mathrm{Zn}$ stored in the aboveground tissues of $S$. nigrum from the pots in which the plants were growing, additional information can be extracted. The data presented on Fig. 4 can be extrapolated to a field situation - considering equal plant development and similar soils characteristics, contamination nature and depth - in order to estimate the number of crops of $S$. nigrum required to clean-up the soil to a certain level. The background levels for agricultural soils should not be higher than $150-300 \mathrm{mg} \mathrm{Zn} \mathrm{kg}{ }^{-1}$ dry soil, for soils with $\mathrm{pH}$ ranging from 6 to 7 (European Council Directive 86/ 278/CEE of 12 June 1986). The studied soils are clearly above the established limits and fall within the range of contamination seen as potential for the application of phytoremediation based clean-up strategies, as one of the 

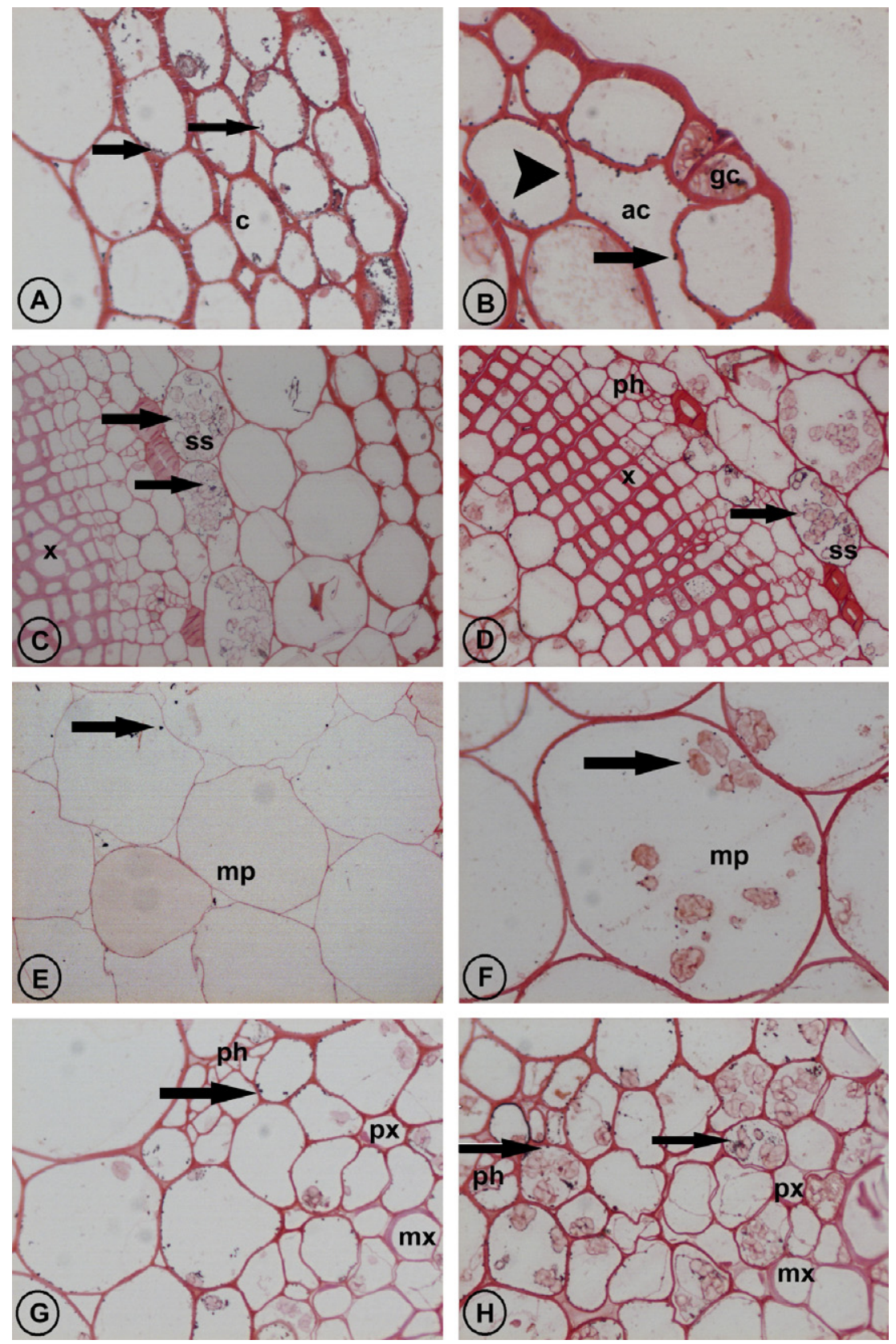

Fig. 5. Light microscopy images of stem cross-sections of plants treated with EDDS (A, C, E, G) or EDTA (B, D, F, H).
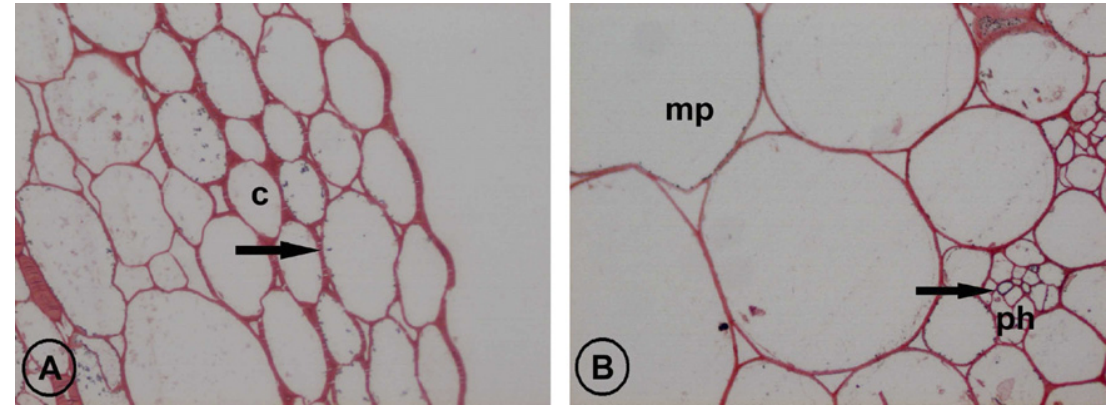

Fig. 6. Light microscopy images of stem cross-sections of plants without without chelating agent treatment. 
disadvantages of the technique is the possible toxicity of high levels of metals present in the soil to plants (Glass, 2000). If only $S$. nigrum was applied to the local soil (L), a minimum of 23 crops would be necessary to achieve soil cleanup, according to those standards, while the extra- $\mathrm{Zn}$ spiked soil would have to undergo a minimum of $42 \mathrm{crops}$ of the plant. This would correspond to a time span of ca. 12-21 years. In general, all the other treatments applied (AMF and/or chelating agents) increased the soil $\mathrm{Zn}$ decontamination abilities of the plant. In some cases this increase was similar or higher with the sole inoculation with AMF than with the application of chelating agents, but the application of EDTA, especially when associated with one of the AMF [ $G$. intraradices in the case of the local soil (L) and G. claroideum in the case of the extra$\mathrm{Zn}$ spiked $(\mathrm{L}+\mathrm{Zn})$ soil] appears as the treatment that is able to enhance to significantly higher levels the $\mathrm{Zn}$ taken up from the soil by $S$. nigrum. These offtakes of $\mathrm{Zn}$ would imply a minimum sequence of 13 and 14 crops to achieve soil cleanup, for the local (L) and the extra-Zn spiked $(\mathrm{L}+\mathrm{Zn})$ soils respectively, which would correspond to a time spam of ca. 7 years. Despite the possible time span reduction brought by a chelate enhanced strategy, phytoextraction using the tested combinations is still a time-consuming remediation strategy and the application of EDTA has some risks at the level of metal percolation.

\section{Conclusions}

This study demonstrated that EDDS and EDTA are equally efficient in increasing the concentrations of $\mathrm{Zn}$ in the tissues of $S$. nigum grown in metal contaminated soils. The lower toxicity of EDDS is indicated by a reduced decrease in the AMF colonisation of $S$. nigrum roots, and by less toxicity signs in the plants exposed to that chelating agent, when compared to EDTA. In addition, the level of $\mathrm{Zn}$ availability in water after harvest when EDDS was applied to the soil was similar or even lower than that registered for the EDTA-treated soil. However, EDTA in association with one of the tested AMF appeared as the soil treatment that enhanced to higher levels the amount of $\mathrm{Zn}$ taken up from the soil to the aboveground tissues of the plant, thus being the treatment that better promoted the phytoextraction abilities of $S$. nigrum and reduced the time-consumption inherent to this technique.

\section{Acknowledgements}

The authors wish to thank Câmara Municipal de Estarreja for the provision of access to the site. This work was supported by Fundação para a Ciência e a Tecnologia and Fundo Social Europeu (III Quadro Comunitário de apoio), research grants of Ana Marques (SFRH/BD/ 7030/2001) and Rui Oliveira (SFRH/BPD/23749/2005). The authors also like to thank Octel Performance Chemicals for suplying EDDS for the development of this experimental work. Miroslav Vosátka is acknowledged for providing the mycorrhizal fungi inocula. This work was funded by the Project MICOMETA-POCI/AMB/60131/ 2004 financed by Medida V.4-Acção V.4.1 of Programa Operacional Ciência e Inovação 2010 (Fundação para a Ciência e Tecnologia).

\section{References}

Blaylock, M.J., Salt, D.E., Dushenkov, S., Zakharova, O., Gussman, C., Kapulnik, Y., Ensley, B.D., Raskin, I., 1997. Enhanced accumulation of $\mathrm{Pb}$ in Indian mustard by soil applied chelating agents. Environ. Sci. Technol. 31, 860-865.

Blaylock, M.J., Huang, J.W., 2000. Phytoextraction of Metals. In: Raskin, I., Ensley, B.D. (Eds.), Phytoremediation of Toxic Metals: Using Plants to Clean Up the Environment. John Wiley, New York, p. 53.

Borregard, S.O., Rydin, H., 1989. Utilization of waste products and inorganic fertilizer in the restoration of iron-mine tailings. J. App. Eco. 26, 1083-1088

Bucheli-Witschel, M., Egli, T., 2001. Environmental fate and microbial degradation of aminopolycarboxylic acids. FEMS Microbiol. Rev. 25, 69-106.

Chaney, R.L., 1989. Toxic Element Accumulation in Soils and Crops: Protecting Soil Fertility and Agricultural Food-Chains. In: Bar-Yosef, B., Barrow, N.J., Goldshmid, J. (Eds.), Inorganic Contaminants in the Vadose Zone. Springer-Verlag, Berlin, pp. 140-158.

Chen, B., Shen, H., Li, X., Feng, G., Christie, P., 2004. Effects of EDTA application and arbuscular mycorrhizal colonization on growth and zinc uptake by maize (Zea mays L.) in soil experimentally contaminated with zinc. Plant Soil 261, 219-229.

Chen, X., Wu, C.H., Tang, J.J., Hu, S.J., 2005. Arbuscular mycorrhizae enhance metal uptake and growth of host plants under a sand culture experiment. Chemosphere 60, 665-671.

Citterio, S., Prato, N., Fumagalli, P., Aina, R., Massa, N., Santagostino, A., Sgorbati, S., Berta, G., 2005. The arbuscular mycorrhizal fungus Glomus mosseae induces growth and metal accumulation changes in Cannabis sativa L. Chemosphere 59, 21-29.

Danscher, G., Montagnese, C., 1994. Autometallographic localization of synaptic vesicular $\mathrm{Zn}$ and lysosomal gold, silver and mercury. J. Histotechnol. 17, 15-21.

De Koe, T., 1994. Agrostis castellana and Agrostis delicatula on heavy metal and arsenic enriched sites in NE Portugal. Sci. Total Environ. $145,103-109$.

Diaz, G., Azconaguilar, C., Honrubia, M., 1996. Influence of arbuscular mycorrhizae on heavy metal $(\mathrm{Zn}$ and $\mathrm{Pb})$ uptake and growth of Lygeum spartum and Anthyllis cytisoides. Plant Soil 180, 241249 .

European Council Directive 86/278/CEE of 12 June 1986, on the protection of the environment, and in particular of the soil, when sewage sludge is used in agriculture as amended by Council Directive 91/692/EEC (further amended by Council Regulation 1882/2003/EC), and Council Regulation 807/2003/EC.

Giovannetti, M., Mosse, B., 1980. An evaluation of techniques for measuring vesicular arbuscular mycorrhizal infection in roots. New Phytol. 84, 489-500.

Glass, D.J., 2000. Economic Potential of Phytoremediation. In: Raskin, I., Ensley, B.D. (Eds.), Phytoremediation of Toxic Metals: Using Plants to Clean Up the Environment. Wiley, New York, USA, p. 18.

Göhre, V., Paszkowski, U., 2006. Contribution of the arbuscular mycorrhizal symbiosis to heavy metal phytoremediation. Planta 223, $1115-1122$

Goodfellow, M., Brown, A.M., Cai, J., Chu, J., Collins, M.D., 1997. Amycolatopsis japonicum sp. nov., an actinomycete producing $(S, S)$ $N, N$ 'ethylenedisuccinic acid. Syst. Appl. Microbiol. 20, 78-84.

Grčman, H., Vodnik, D., Velikonja-Bolta, S., Lestan, D., 2003. Ethylenediaminedissucinate as a new chelate for environmentally safe enhanced phytoextraction. J. Environ. Qual. 32, 500-506. 
Heumann, H.G., 2002. Ultrastructural localization of $\mathrm{Zn}$ in Zn-tolerant Armeria maritime ssp. Halleri by autometallography. J. Plant Physiol. 159, 191-203.

Houba, V.J.G., van der Lee, J.J., Novozamsky, I., 1995. Soil Analysis Procedures. Department of Soil Science and Plant Nutrition, Wageningen Agricultural University. Syllabus, Wageningen.

Huang, J.W., Chen, J., Berti, W.R., Cunningham, S.D., 1997. Phytoremediation of lead contaminated soils: role of synthetic chelates in lead phytoextraction. Environ. Sci. Technol. 31, 800-805.

Johnson, N.C., Graham, J.H., Smith, F.A., 1997. Functioning of mycorrhizal associations along the mutualism-parasitism continuum. New Phytol. 135, 575-585.

Joner, E.J., Leyval, C., 1997. Uptake of 109Cd by roots and hyphae of a Glomus mosseae / Trifolim subterraneum mycorrhiza from soil amended with high and low concentration of cadmim. New Phytol. 135, 353-360.

Kabata-Pendias, A., Pendias, H., 1984. Trace Elements in Soils and Plants. CRC Press, Boca Raton, Florida.

Kayser, A., Wenger, K., Keller, A., Attinger, W., Felix, H.R., Gupta, S.K., Schulin, R., 2000. Enhancement of phytoextraction of $\mathrm{Zn}, \mathrm{Cd}$ and $\mathrm{Cu}$ from calcareous soil: the use of NTA and sulphur amendments. Environ. Sci. Technol. 34, 1778-1783.

Lai, H.Y., Chen, Z.S., 2004. Effects of EDTA on solubility of cadmium, zinc, and lead and their uptake by rainbow pink and vetiver grass. Chemosphere 55, 421-430.

Lombi, E., Zhao, F.J., Dunham, S.J., McGrath, S.P., 2001. Phytoremediation of heavy metal contaminated soils: natural hyperaccumulation versus chemically enhanced phytoextraction. J. Environ. Qual. 30, 1919-1926.

Luo, C., Shen, Z., Li, X., Baker, A.J.M., 2006. Enhanced phytoextraction of $\mathrm{Pb}$ and other metals from artificially contaminated soils through the combined application of EDTA and EDDS. Chemosphere 63, 17731784.

Luo, C., Shen, Z., Li, X., 2004. Enhanced phytoextraction of Cu, Pb, Zn and Cd with EDTA and EDDS. Chemosphere 59, 1-11.

Marques, A.P.G.C., Oliveira, R.S., Rangel, A.O.S.S., Castro, P.M.L., 2006. Zinc accumulation in Solanum nigrum is enhanced by different arbuscular mycorrhizal fungi. Chemosphere 65, 1256-1263.

Marques, A.P.G.C., Oliveira, R.S., Samardjieva, K.A., Pissarra, J., Rangel, A.O.S.S., Castro, P.M.L., 2007a. Solanum nigrum grown in contaminated soil: effect of arbuscular mycorrhizal fungi on zinc accumulation and histolocalisation. Environ. Pollut. 145, 691-699.

Marques, A.P.G.C., Oliveira, R.S., Rangel, A.O.S.S., Castro, P.M.L., 2007b. Zn accumulation in plant species indigenous to a Portuguese polluted site: relation with soil contamination. J. Environ. Qual. 36, 643-653.
Marques, A.P.G.C., Rangel, A.O.S.S., Castro, P.M.L., 2003. The uptake of heavy metals in plant species endemic to a polluted stream near an industrialized region of Portugal. In: Neves, M., Neves, A.C.V. (Eds.), Proceedings of the International Symposium Environment 2010 Situation and Perspectives for the European Union. Universidade do Porto - Faculdade de Engenharia, Porto, p. A01.

Meers, E., Ruttens, A., Hopgood, M.J., Samson, D., Tack, F.M.G., 2005. Comparison of EDTA and EDDS as potential soil amendments for enhanced phytoextraction of heavy metals. Chemosphere 58, 10111022.

Nörtemann, B., 1999. Biodegradation of EDTA. Appl. Microbiol. Biot. $51,751-759$.

Norwell, W.A., 1991. Reactions of metal chelates in soils and nutrient solution. In: Mortvedt, J.J. (Ed.), Micronutrients in Agriculture, 2nd ed. Soil Science Society of America, Madison, pp. 187-227.

Oliveira, R.S., Dodd, J.C., Castro, P.M.L., 2001. The mycorrhizal status of Phragmites australis in several polluted soils and sediments of an industrialised region of Northern Portugal. Mycorrhiza 10, 241-247.

Oliveira, R.S., Castro, P.M.L., Dodd, J.C., Vosatka, M., 2006. Different native arbuscular mycorrhizal fungi influence the coexistence of two plant species in a highly alkaline anthropogenic sediment. Plant Soil 287, 209-221.

Phillips, J.M., Hayman, D.S., 1970. Improved procedures for clearing and staining parasitic and vesicular-arbuscular mycorrhizal fungi for rapid assessment of infection. T. Brit. Mycol. Soc. 55, 158-161.

Schowanek, D., Feijtel, T.C.J., Perkins, C.M., Hartman, F.A., Federle, T.W., Larson, R.J., 1997. Biodegradation of $[S, S][R, R]$ and mixed stereoisomers of ethylene diamine dissucinic acid (EDDS), a transition metal chelator. Chemosphere 34, 2375-2391.

Smith, S.E., Read, D.J., 1997. Mycorrhizal Symbiosis. Academic Press Limited, London.

Sudová, R., Pavlíková, D., Macek, T., Vosátka, M., 2007. The effect of EDDS chelate and inoculation with the arbuscular mycorrhizal fungus Glomus intraradices on the efficacy of lead phytoextraction by two tobacco clones. App. Soil Ecol. 35, 163-173.

Turgut, C., Pepe, M.K., Cutright, T.J., 2005. The effect of EDTA on Helianthus annus uptake, selectivity, and translocation of heavy metals when grown in Ohio, New Mexico and Colombia soils. Chemosphere 58, 1087-1095.

Wallinga, I., Vark, W., Houba, V.J.G., Lee, J.J., 1989. Plant Analysis Procedures. Department of Soil Science and Plant Nutrition. Wageningen Agricultural University, Syllabus, Wageningen.

Wu, L.H., Luo, Y.M., Xing, X.R., Christie, P., 2004. EDTA-enhanced phytoremediation of heavy metals contaminated soil with Indian mustard and associated potential leaching risk. Agr. Ecosystems Environ. 102, 307-318. 